\title{
Childhood Trauma as a risk factor for suicidal behaviour in prisons
}

\author{
Navarro-Atienzar F $F^{1}$, Zabala-Baños $\mathrm{C}^{2}$, Ricarte-Trives JJ ${ }^{3}$ \\ ${ }^{1}$ University of Castilla-La Mancha. Master's Degree in Criminology and Young Offenders. Faculty of Law. Albacete. \\ ${ }^{2}$ University of Castilla-La Mancha. Faculty of Occupational Therapy, Speech Therapy and Nursing. Talavera de \\ la Reina. Toledo. \\ ${ }^{3}$ University of Castilla-La Mancha. Faculty of Medicine. Albacete.
}

\begin{abstract}
Suicide is a public health problem worldwide. Although it affects people of any age, race, gender, nationality or culture, the studies reveal that one of the groups that present high risk are the inmates of a penitentiary institution, with suicide figures higher than those of the general population. In recent years, penitentiary institutions around the world are trying to reduce cases of suicide deaths through prevention and early detection programs. However, in countries such as the United Kingdom, Wales or Spain, the figures are still very high.

Researchers and professionals from different disciplines have tried to establish the causes and risk factors that can lead to committing suicide. Among them, suffering traumatic events in childhood (childhood trauma) has been established as one of these factors. Recent studies have shown that childhood trauma has a significant incidence in the prison population, thus assuming an important specific risk factor in this population.

The objective of this article is to review the risk factors associated with suicide in the penitentiary institution in order to understand the role of childhood trauma, its emotional impact and its relation to suicidal behavior in the prison environment, thereby contributing to the understanding and management of the cases having repercussions in an improvement in the programs for the prevention of suicide in prisons.
\end{abstract}

Keywords: suicide, risk factors, prisons, prevalence.

Text received: 02/02/2018

Text acepted: 25/05/2018

\section{INTRODUCTION}

Suicide is a major health problem worldwide. About 800,000 people die from suicide every year ${ }^{1}$. In Spain it is the primary cause of unnatural death and is more common than death from traffic accidents ${ }^{2}$. Although suicide affects general public, it is one of the most common causes of death in prison worldwide. Inmates are a high-risk group in this regard, with a ratio of suicide considerably higher than that of the general public ${ }^{3-5}$ (usually more than 3 amongst men and 9 amongst women ${ }^{6}$ ). Such is the degree of concern that the World Health Organisation (WHO) established suicide as a healthcare priority in prisons.
Furthermore, a number of countries are witnessing an increase in cases within the penitentiary systems. The Scandinavian countries show one of the highest rates in Europe, with more than 100 suicides per 100,000 inmates $^{6}$, along with Cyprus, with a ratio of 44.1 for each 10,000 inhabitants ${ }^{7}$, and the UK, where it increased by $28 \%$ last year ${ }^{8}$. It is the first cause of death in American prisons, where the ratio in 2013 was $34 \%$, which was a significant increase of $14 \%$ in comparison to the year before 9 . In Spain, a total of 31 suicides took place inside Spanish prisons, which is $19.7 \%$ of the total number of deaths there ${ }^{10}$. However, such a high number of cases makes for a contrast with the decrease in the prison population since 
2009, as shown in Table 1, where it can be seen that although the number of male and female inmates has progressively decreased in recent years, and the distribution of inmates by gender has not significantly varied, the number of cases of suicide by women in Spanish women has considerably increased, reaching almost $15 \%$ of the total number of cases in 2015 . This data indicates a highly significant increase in comparison to previous years, as Table 2 shows. However, this apparent upward trend in suicides amongst women is not limited solely to Spain. Similar figures can be seen in the UK, which highlight the fact that women present more mental health problems and more episodes of suicide than in the past (Prisons E Probation Ombudsman $\left.{ }^{11}\right)$. In Spain the number dropped to 23 in 2015, and fell to 21 in $2016^{12}$.

For decades, researchers and professionals from different disciplines have attempted to determine the factors that can drive a person to commit suicide. Some of these risk factors, which do not necessarily have be the cause of the act, are psychopathological disorders, family background, alcohol and/or drug abuse, and hopelessness or a history of child abuse. The last factor is important inasmuch as a number of studies have shown that traumatic experiences in infancy may be a risk factor for future suicidal behaviours ${ }^{13,14}$. However, studying correlations between childhood trauma and suicidal behaviour in prison is more complex than amongst the general public. The main reason for this is the greater risk of intrinsic suicide in prisons, due to the exposure of inmates to a multitude of risk factors that may not be present outside prisons and which are a traumatic experience, at least to start with.

The aim of this review study is to highlight the existence of a relationship between childhood trauma (caused by abuse and/or neglect) and the existence of suicidal behaviours amongst men and women that are serving their sentence in prison, and to understand the impact that such a trauma can have on suicidal behaviours amongst inmates. By understanding this relation (if there is one), it may be possible to make a positive contribution in assessing possible measures that can help to mitigate this problem.

\section{MATERIALS AND METHODS}

This review was prepared using the data and information obtained from a total of 55 bibliographi-

Table 1. History of prison population in Spain (2012-2015) with gender differences.

\begin{tabular}{llllll}
\hline Year & & Men & $\%$ Men & Women & \% Women \\
\hline 2012 & 68,597 & 63,372 & $92.39 \%$ & 5,225 & $7.61 \%$ \\
\hline 2013 & 66,765 & 61,682 & $92.39 \%$ & 5,083 & $7.61 \%$ \\
\hline 2014 & 65,017 & 60,040 & $92.35 \%$ & 4,977 & $7.65 \%$ \\
\hline 2015 & 61,614 & 56,892 & $92.34 \%$ & 4,722 & $7.66 \%$ \\
\hline
\end{tabular}

Note. Source: Own research based on data extracted from: Prisons. En: 2015 Statistical Yearbook of the Ministry of the Interior. Ministry of the Interior; 2015. p. 522-603.

Table 2. Total deaths and deaths from suicide in Spanish prisons (2012-2015) with gender differences.

\begin{tabular}{|c|c|c|c|c|c|}
\hline Year & $\begin{array}{c}\text { Total number of } \\
\text { deaths in } \mathrm{P}\end{array}$ & Deaths from suicide & $\%$ Suicide & $\begin{array}{l}\text { Deaths of women } \\
\text { from suicide in } \mathrm{P}\end{array}$ & \% Women \\
\hline 2012 & 191 & 30 & $15.7 \%$ & 1 & $3.3 \%$ \\
\hline 2013 & 224 & 39 & $17.4 \%$ & 3 & $7.7 \%$ \\
\hline 2014 & 157 & 31 & $19.7 \%$ & 5 & $16.1 \%$ \\
\hline $2015 *$ & 155 & 23 & $14.8 \%$ & 3 & $13.04 \%$ \\
\hline
\end{tabular}

Note. Own research based on data from reports SPACE I of 2013, 2014 and 2015, (Council of Europe Annual Penal Statistics).

*The data of 2015 corresponds to prisons nationwide, but does not include those of the Community of Catalonia. P: prisons. 
cal references, and important part of which are scientific and research articles.

Searches were carried out in the following data bases: PubMed, Psychinfo, SciELO y Google Scholar, so as to localise and obtain the articles. The following criteria were used to define the search: in all cases the searches were confined to articles in Spanish and English; the search for type of sources was limited to scientific articles, books, papers in conferences and publications by official bodies. No time or geographical restriction was applied, and only those studies in which the sample was made up of persons of legal age were included.

The key words and the MeSH terms (Medical Subject Headings) relating to childhood trauma and suicide were then selected. The key words used in Spanish were "trauma infantil", "abuso infantil", "negligencia infantil" "trastorno de estrés postraumático", "instituciones penitenciarias", "suicidio en prisiones" "cárcel (-es)". The terms used in English were "childhood abuse", "child neglect", "childhood trauma", "PTSD", "penitentiary institution (-s)", "prison (-s), prison suicide (-s)" e "inmate suicide (-s)". The key words correspond to two blocks: the first related to childhood abuse and trauma; and the second one with prisons, penitentiary institutions and suicide.

When the searches were conducted in the data bases, the first search used isolated searches (one single term). Then cross searches were carried out, simultaneously selecting one key word form each block.
The portals of official bodies and agencies on the Internet were consulted to obtain and localise data and publications from said bodies, both at national (SGII) and international levels (United Nations Organisation).

Table 3 shows the data bases that were consulted, the number of resulting articles (separately and in total) and the filters applied until the final selection of studies was obtained. Table 4 summarises the main results found in the papers reviewed in this study on the history of trauma and suicide in the prison population.

\section{CHILDHOOD TRAUMA AS A RISK FACTOR FOR SUICIDE IN PRISON}

The traumatic events that can be experienced in childhood are many and varied. Some may be isolated episodes, such as suffering from a traffic accident or living through a natural disaster, but others, such as child abuse, may occur on a continuous basis, and endanger the physical safety of the minor and expose him or her to severe negative consequences, such as the development of mental illnesses or committing violent and/or criminal offences. Child abuse is defined as abuse and neglect suffered by minors under 18 years of age, and includes type of physical or psychological abuse, sexual abuse, lack of care, neglect and commercial or other types of exploitation that cause or may cause damage to the health development or dignity of the minor ${ }^{15}$.

Table 3. Procedure and criteria followed for selection of studies.

\begin{tabular}{|c|c|c|c|c|c|}
\hline \multirow[t]{2}{*}{ Selection criteria/filters } & \multicolumn{4}{|c|}{ Data bases } & \multirow[t]{2}{*}{ Total studies } \\
\hline & PubMed & PsychINFO & SciELO & Google Scholar & \\
\hline $\begin{array}{l}\text { Studies identified in the } \\
\text { data bases (without filters }\end{array}$ & $\mathrm{N}=944$ & $\mathrm{~N}=1,849$ & $\mathrm{~N}=514$ & $\mathrm{~N}=1,011$ & $\mathrm{~N}=3,115$ \\
\hline $\begin{array}{l}\text { Studies eliminated due to } \\
\text { duplication }\end{array}$ & \multicolumn{4}{|c|}{$\mathrm{N}=416$} & $\mathrm{~N}=2,699$ \\
\hline $\begin{array}{l}\text { Studies selected for title } \\
\text { and abstract }\end{array}$ & \multicolumn{4}{|c|}{$\mathrm{N}=257$} & $\mathrm{~N}=257$ \\
\hline $\begin{array}{l}\text { Studies eliminated for } \\
\text { not having free access to } \\
\text { complete text }\end{array}$ & \multicolumn{4}{|c|}{$\mathrm{N}=213$} & $\mathrm{~N}=44$ \\
\hline $\begin{array}{l}\text { Studies selected by other } \\
\text { sources }\end{array}$ & \multicolumn{4}{|c|}{$\mathrm{N}=12$} & $\mathrm{~N}=12$ \\
\hline Studies finally included & \multicolumn{4}{|c|}{$\begin{array}{c}44 \text { scientific articles } \\
11 \text { publications from official bodies } \\
1 \text { book }\end{array}$} & $\mathrm{N}=56$ \\
\hline
\end{tabular}


According to the studies, about $60 \%$ of children and adolescents have experienced or observed a potentially traumatic situation at some moment in their lives ${ }^{16}$.

Data from the $\mathrm{WHO}^{15}$ also shows that in global terms one fourth of all adults state that they have suffered physical abuse in childhood and more specifically, one out of every five women and one out of every thirteen men declares that they have suffered from sexual abuse in their childhood. Many children are also subject to psychological or emotional abuse and are victims of neglect. In Spain, the prevalence of some type of abuse of minors is situated at between 3 and $6 \%{ }^{17}$.

Depending on the characteristics of each person, their surroundings and their coping skills, such traumatic episodes may in some cases have no repercussions on a person's life beyond the event itself; but in other cases, it may lead to future short, medium or long term complications, depending on the type and intensity of the act, on the age of the minor when it took place or the socio-demographic characteristics. Despite this highly complex state of affairs, recent decades have seen intense research work being carried out to detect and document the long-term effects of childhood abuse on those who have experienced it.

A number of studies and research projects have managed to establish correlations between childhood trauma and different conditions, such as depressive disorders ${ }^{18}$, post-traumatic stress disorder (PTSD) ${ }^{19}$, anxiety disorders $\mathrm{s}^{20}$, consumption of illegal substances $^{21}$, risk of emotional distress ${ }^{22}$, suicidal behaviour ${ }^{14,15}$, biological effects on memory and social $\operatorname{cognition}^{23}$, and even a reduced life expectancy ${ }^{24}$. The prison population is regarded as a group at risk, since the most characteristic group is made up of persons

Table 4. Summary of main findings on trauma and suicide in the prison population.

\begin{tabular}{|c|c|c|c|}
\hline Authors & $\begin{array}{l}\text { Characteristics of the } \\
\text { sample }\end{array}$ & Results & Conclusions \\
\hline Roy (2011) & $\begin{array}{l}281 \text { patients with drug } \\
\text { dependence and family } \\
\text { history of suicidal } \\
\text { behaviour. }\end{array}$ & $\begin{array}{l}\text { Suffering traumatic events } \\
\text { in childhood increases } \\
\text { the risk of suicide in } \\
\text { adulthood. }\end{array}$ & $\begin{array}{l}\text { Individuals at risk of suicide attempts } \\
\text { present more histories of childhood } \\
\text { trauma. }\end{array}$ \\
\hline $\begin{array}{l}\text { Gorodetsky, Carli, } \\
\text { Sarchiapone, Roy, } \\
\text { Goldman \& Enoch } \\
\text { (2016) }\end{array}$ & 702 Italian men in prison. & $\begin{array}{l}\text { Physical abuse means an } \\
\text { increased risk of suicide } \\
\text { and of self-harming } \\
\text { behaviours (in men). }\end{array}$ & $\begin{array}{c}\text { In men there is a correlation between a } \\
\text { history of physical abuse and the risk } \\
\text { of suicide. }\end{array}$ \\
\hline $\begin{array}{l}\text { Swogger, Sungeun, } \\
\text { Cashman-Brown \& } \\
\text { Conner }(2010)\end{array}$ & $\begin{array}{l}266 \text { criminal offenders } \\
\text { between } 18 \text { and } 62 \text { years. }\end{array}$ & & \\
\hline $\begin{array}{l}\text { Charles, Abram, } \\
\text { McClelland \& Teplin } \\
(2003)\end{array}$ & 1,272 women in prison. & $\begin{array}{l}\text { There is a similar risk of } \\
\text { suicide in prison for men } \\
\text { and women. }\end{array}$ & $\begin{array}{c}\text { There are no significant gender } \\
\text { differences with regard to risk of } \\
\text { suicide. }\end{array}$ \\
\hline $\begin{array}{l}\text { Mandellia, Carlib, Roy, } \\
\text { Serrettia \& Sarchiapone } \\
\text { (2011) }\end{array}$ & 1,553 prisoners & $\begin{array}{l}\text { Sexual abuse is a risk factor } \\
\text { in repetition of suicidal } \\
\text { behaviours. }\end{array}$ & $\begin{array}{l}\text { Inmates with histories of sexual abuse, } \\
\text { regardless of gender, shall present more } \\
\text { risk and/or history of repetition of } \\
\text { suicidal behaviours. }\end{array}$ \\
\hline $\begin{array}{l}\text { Clements-Nolle, } \\
\text { Wolden \& } \\
\text { Bargmann-Losche } \\
(2009)\end{array}$ & $\begin{array}{l}247 \text { women incarcerated in } \\
\text { a state prison in Las Vegas } \\
\text { (Nevada, USA).. }\end{array}$ & $\begin{array}{l}\text { Childhood trauma is an } \\
\text { independent risk factor for } \\
\text { suicide attempts in the past } \\
\text { and possibility of future } \\
\text { suicide attempts amongst } \\
\text { women in prison. }\end{array}$ & $\begin{array}{l}\text { Childhood trauma is confirmed as an } \\
\text { independent risk factor of suicide in } \\
\text { prison. }\end{array}$ \\
\hline $\begin{array}{l}\text { Caravaca, Fearn } \\
\text { \&Vaughn M (2017) }\end{array}$ & $\begin{array}{l}2,270 \text { hombres men } \\
\text { incarcerated in seven } \\
\text { Spanish prisons. }\end{array}$ & $\begin{array}{l}\text { Childhood trauma is one } \\
\text { of the risk factors related } \\
\text { to almost fatal suicidal acts } \\
\text { amongst Spanish prisoners. }\end{array}$ & $\begin{array}{l}\text { About } 74 \% \text { of prisoners that presented } \\
\text { almost fatal suicide attempts also } \\
\text { showed presence of some level of } \\
\text { childhood trauma, compared to } 59 \% \text { of } \\
\text { the participants who had not attempted } \\
\text { suicide. }\end{array}$ \\
\hline
\end{tabular}


who have lived in depressed environments, with difficult life histories, and many of them have suffered from abuse, abandonment, physical or verbal abuse, defective socialisation processes and family and social contexts where there is a lack of basic necessities. All the above leads to a psychological profile characterised by a high frequency of exposure to traumatic events, abusive consumption of drugs and alcohol and a high prevalence of mental health problems. These three characteristics are significantly more common amongst inmates than in the general population ${ }^{25}$. Many research projects have highlighted the relationship between traumatic events and their link to, for example, violent or maladapted behaviours, such as victimisation. Studies ${ }^{26}$ carried with young recidivists showed that of the 25 that had suffered head injuries, 15 committed self-injury and 10 attempted suicide. Results on the type of trauma according to gender in the prison environment are contradictory, as there are studies that refer both to the frequency and exposure to trauma, which is similar in both sexes ${ }^{27}$, except where sexual abuse and aggression is concerned, which was more common amongst women ${ }^{28}$; and in mean, being witness or victim to physical violence, where also exposure to trauma in the past is a significant predictor of violent behaviours and victimisation in prison, especially when the frequency of traumatic events at an early age was high ${ }^{26}$.

However, as mentioned above, the nature of the abuse must be taken into account before reaching any conclusions. Some authors ${ }^{29}$ observed a number of interesting differences in terms of the psychopathological effects of the different types of trauma. Physical and sexual abuse present high levels of correlation with PTSD, and sexual abuse has a high correlation with bipolar disorder, although these results should be taken with some precaution. A relationship has also been observed between complex trauma and the development of borderline personality disorder, one of the most common personality disorders of its type, which is related to childhood emotional ${ }^{30}$ and sexual abuse in between 40 and $70 \%$ of cases $^{31}$.

Some studies have tried to ascertain the impact of different types of abuse on future suicidal behaviours and found that, although several types of abuse are related to suicidal behaviour, sexual abuse appears to be the most strongly linked ${ }^{32}$. In any case, there is scientific evidence that suggests that these acts may be a risk factor for future suicidal behaviour. In some sectors of the population, as is the case of people in prison, it may be an extra risk, as it combines with a multitude of factors intrinsic to confinement in a prison. Studies carried out on the general public ${ }^{33}$ confirmed the hypothesis that childhood trauma presented a significant correlation with suicidal patients when compared to the control group ${ }^{34,35}$, and the same results were detected amongst inmates that had attempted to commit suicide, who were more likely to have a history of childhood trauma ${ }^{36}$. However, studying the correlations between childhood trauma and suicidal behaviour is a more complex process in prisons than in the outside world. The main reason is the greater risk of suicide intrinsic to prisons, as the fact of being confined exposes individuals to a multitude of risk factors that might not appear amongst the general population, such as the psychological impact of detention and imprisonment, the daily stress implicit in prison life, the repercussions of their criminal activity in the media, the depression produced in people who have committed economic crimes when a type of economic reality disappears, separation from or loss of family and social links, mental illness, chronic substance abuse and a criminal record ${ }^{37}$. But despite these difficulties, several authors ${ }^{38}$ have carried out studies that have found a risk of suicide of $27 \%$ in prisons, in comparison to $3.6 \%$ in the general population, and between 41 and $50 \%$ had experienced severe childhood abuse in their infancy ${ }^{39}$.

As to when such suicidal behaviours amongst prisoners commence and are repeated, several studies ${ }^{40}$ confirmed that inmates that had attempted suicide presented higher value in the scale of the Childhood Trauma Questionnaire (CTQ). They also detected that repetition of suicide attempts was solely related to sexual abuse.

Studies ${ }^{41}$ on predictors of self-harming behaviours have revealed that only physical abuse had an independent effect on self-directed aggressive behaviours, and that this trauma from physical abuse also meant an increase in the risk of suicide and in the likelihood of future attempts ${ }^{42}$.

Research on this subject has also been carried out in Spain. Some authors ${ }^{43}$ explored the risk of suicide amongst male inmates, measuring demographic variables, personality disorders, psychopathological disorders and the risk of suicide. The results showed that $33.5 \%$ of the sample were at risk of suicide and a study on associated risk factors conducted at six Span- 
ish prisons ${ }^{44}$, with an initial sample of 5,000 , detected that $74 \%$ of the inmates that had attempted suicide at some time presented a history of childhood abuse, compared to $59 \%$ of the participants that had not attempted any suicidal acts. Possible gender differences have also been the subject of research in recent years. Although the vast majority of studies carried out in this area have studied male populations (due to the predominance of men in prisons), other authors ${ }^{45}$ have carried out studies on the female prison population, and found that sexual abuse (and not physical) had an effect on suicidal behaviour. Studies were also conducted to see if childhood trauma was an independent risk factor for attempted suicide in the past and the probability of repeating the attempt in future, and results showed that the existence of childhood trauma was in itself a risk factor, both for previous attempts and for future suicidal episodes ${ }^{46}$.

\section{THE INCIDENCE OF CHILDHOOD TRAUMA IN THE PRISON POPULATION}

Published studies have managed to establish correlations between traumatic events at an early age and future criminal behaviour, both in infancy and adolescence, and as an adult ${ }^{47-49}$, and found that more than $90 \%$ of young offenders have suffered at least one traumatic event in their past, and that over $50 \%$ of adults in prison had suffered some type of moderate or severe trauma ${ }^{38}$.

This findings may indicate that childhood trauma is very much present within the justice system, both amongst men and women and amongst adults and young people. Different studies ${ }^{50,51}$ found a significantly higher prevalence of post-traumatic stress disorder amongst young offenders than amongst young people who have not committed any crime. It was also detected that $70 \%$ of women in prison were victims of family violence during their childhood or adolescence ${ }^{52}$. Similar research work ${ }^{53}$ found that $78 \%$ of women in prison had experienced at least one type of trauma. Subsequent studies ${ }^{54}$ detected significantly high levels of traumatic experiences, such as sexual abuse $(53 \%)$, physical abuse $(42 \%)$ and neglect $(22 \%)$ in their sample of women in a prison in New Mexico.

Therefore, the published studies have shown that there is a considerable presence of childhood trauma amongst persons that are serving prison sentences in different regions and countries. As we pointed out above, such traumatic experiences may imply a risk of future suicidal behaviours in prison (apart from those triggered by other factors). In view of this situation, the Prison Institution in Spain developed action and prevention programmes and in 2005 set up the Framework Programme for Prevention of Suicide in Prisons (Programa Marco Prevención de Suicidios en los Centros Penitenciarios (PPS)), which underwent a review in 2014 for analysis and improvement. The programme consists of a protocol of measures directed to all professionals working in prisons, in order to identify inmates and personal and social situations that imply or may imply a high risk of suicide, such as committing severe offences against persons, a history of attempts, or behaviours, that are suicidal or self-harming, a severe disease, family loss or break ups, the impact of entry into prison, consumption of alcohol and drugs, social isolation or psychopathological disorders (some of the psychopathological disorders mentioned are schizophrenia and depressive disorders), for the subsequent application of more appropriate and effective intervention measures so as to prevent self-harming behaviours. This programmes is complemented with the figure of the "inmate listener", an inmate trusted by the healthcare and technical team of the facility, who has received specialised training and who is responsible for being 24 hours a day with the inmate who has committed self-harm, attempted suicide or presents a high risk, and monitors their conduct. 2,456 inmates formed part of this programme in $2016^{55}$.

Although there is no mention of childhood trauma or post-traumatic stress disorder in this programme, it does mention psychopathological conditions as risk factors. However, as we stated previously, being a victim of abuse, neglect or abandonment in infancy may be a risk factor for suicide, without any psychopathological diagnosis being required, which means that such cases may go undetected, since they do not fit in with any of the risk factors that are listed.

Women may also find themselves in situations of greater risk as they are exposed to traumatic events of different types and/or intensity, while data on the increase of suicides by women in recent years has also been seen. 


\section{CONCLUSIONS}

Suicide and childhood abuse are two phenomena that cause tremendous alarm in most societies and communities worldwide. A large number of countries are actively fighting against suicide through dynamic policies of prevention, training and awareness-raising, and by establishing strategies such as early detection, psychological aid and research. Finland has actively struggle against suicide and thanks to this effort has managed to bring about an ongoing decrease in the figures of death by suicide amongst young men, which in 1990 reached the astronomical rate of 49.5 per 100,000 inhabitants (about one case per 2,000 persons).

The same process is taking place with childhood abuse and neglect. In recent decades, the vast majority of developed countries have taken measures, creating programmes and toughening up the law to ensure that minors are protected from this type of abuse. Advances in research in recent years are helping to raise awareness of the damage that such violent and negligent acts can do in the short, medium and long term to the person that has to endure them. As the analysis of this review shows, some of these effects include criminal conduct or suicidal behaviour.

Although the link between childhood trauma and suicide in the general population is well known, the incarceration of an individual in prison is a major aggravating factor, due to the stress of confinement and risk factors associated with serving a prison sentence. A set of phenomena and concepts can be seen in this case (childhood trauma, crime, suicidal behaviours) that are related, combine and form mutual feedback loops. Greater knowledge of how these relationships function may help to improve suicide prevention and, eventually, reduce the number of people who take their own lives in prison.

The authors share the observations made by studies $^{25}$ that highlight the fact that a large percentage of prison inmates have suffered from some type of traumatic event in their childhood, and that this may affect them when they enter prison, together with the presence of anxious-depressive symptoms in the first days of incarceration that may be aggravated, thereby reducing or even eliminating the inmate's capacity to cope with the situation of confinement, which may trigger behaviour leading to suicide.

The studies have plainly shown the existing relationship between the high frequency of exposure to traumatic events amongst inmates and abusive consumption of drugs or alcohol, and both factors tend to be related to the appearance of mental health problems. The high prevalence of inmates that present The high prevalence of inmates who present histories of childhood trauma should be regarded as a predictive factor for suicidal behaviour, and an evaluation of such traumas should be included in the available assessment protocols so as to provide better understanding of the impact that childhood trauma may have on suicidal behaviour amongst inmates, and so positively contribute to the appraisal of possible lines of action that can help to mitigate this problem.

It would also be desirable to consider the need for introducing the examination or detection of trauma as a risk factor in clinical evaluation of inmates with suicidal behaviours or in situations of risk, along with an assessment of emotional factors, psychiatric symptoms, personality variables, the risk of suicide itself, indicators of consumption of substances and an evaluation of daily stress factors in prisons. By doing so, a more accurate and comprehensive overview of the knowledge of the risk of suicide in this group is achieved, which enables more suitable intervention to be established that focuses on the inmates that present a history of suffering from trauma not only in suicide prevention programmes, but also in psychotherapeutic programmes designed to assist in the inmate's personal and psycho-social reparation, as well as in programmes to facilitate adaptation to the prison environment.

\section{CORRESPONDENCE}

Carmen Zabala-Baños

E-mail: Carmen.Zabala@uclm.es

\section{REFERENCES}

1. World Health Organization. Deaths by Cause, Age and Sex, Estimates for 2000-2012. [Internet]. En: Global Health Estimates (GHE). Geneva. [actualizado 2014; citado 1 May 2017]. Disponible en: http://www.who.int/healthinfo/global_ burden_disease/en/

2. Instituto Nacional de Estadística. Estadística de defunciones según la causa de muerte. [Internet; actualizado 21 Dic 2017; citado 20 Ene 2018]. Madrid. Disponible en: http://www.ine. es/dyngs/INEbase/es/operacion.htm?c=Estadist 
ica_C\&cid $=1254736176780 \&$ menu=ultiDatos\&i $\mathrm{d} p=1254735573175$

3. Fazel S, Grann M, Kling B, Hawton K. Prison suicide in 12 countries: an ecological study of 861 suicides during 2003-2007. Soc Psychiatry Psychiatr Epidemiol. 2011;46:191-95.

4. Smith PN, Wolford-Clevenger C, Mandracchia JC, Jahn, DR. An exploratory factor analysis of the Acquired Capability for Suicide Scale in male prison inmates. Psychol Serv. 2013;10:97-105.

5. Steiner B, Butler HD, Ellison JM. Causes and correlates of prison inmate misconduct: a systematic review of the evidence. J Crim Justicia. 2014;42:462-70.

6. Fazel S, Ramesh T, Hawton K. Suicide in prisons: an international study of prevalence and contributings factors. Lancet Psychiatry. 2017;4:946-52.

7. Council of Europe. France: SPACE-Council of Europe Annual Penal Statistics. [Internet]. Strasbourg Cedex. [actualizado 2016]. Disponible en: https://www.coe.int/en/web/prison/space

8. Gov.uk. Safety in custody quarterly update to March 2016. National Statistics. [Internet]. London: Ministry of Justice. [actualizado Mar 2016; citado 7 Sep 2017]. Disponible en: https://www. gov.uk/government/statistics/safety-in-custodyquarterly-update-to-june-2016

9. Noonan ME, Ginder S. Mortality in local jails and state prisons, 2000-2011-statistical tables. Washington, DC: U.S. Departament of Justice, Bureau of Justice Statistics; 2013. Disponible en: https:// www.bjs.gov/content/pub/pdf/mljsp0011.pdf

10. Aebi MF, Delgrande N. Council of Europe Annual Penal Statistics: SPACE I-Prison Populations. Survey 2013. Strasbourg: Council of Europe; 2015. Disponible en: http://wp.unil.ch/space/ files/2015/02/SPACE-I-2013-English.pdf

11. Prisons \& Probation Ombudsman Independent Investigations. Female prisoner deaths rising and prisons must take action, says ombudsman. [Internet; actualizado 2017; citado 2 Dic 2017]. Disponible en: http://www.ppo.gov.uk/wp-content/ uploads/2017/03/PPO-news-release-self-inflicted-deaths-among-women.pdf

12. Secretaría General de Instituciones Penitenciarias. Ministerio del Interior. Mortalidad en Instituciones Penitenciarias (ILPP) año 2015 (y 2). Boletín epidemiológico de Instituciones Penitenciarias. 2017;22. Disponible en: http://www.institucionpenitenciaria.es/web/export/sites/default/datos/descargables/saludpublica/BOLETIN_02-2017.pdf

13. Roy A. Combination of family history of suicidal behavior and childhood trauma may represent correlate of increased suicide risk. J Affect Disord. 2011;130:205-8.

14. Sarchiapone M, Carli V, Cuomo C, Roy A. Childhood trauma and suicide attempts in patients with unipolar depressed. Depress Anxiety. 2007;24,268-72.

15. Organización Mundial de la Salud. Maltrato infantil. [Internet]. 2016. Disponible en: http:// www.who.int/mediacentre/factsheets/fs150/es/

16. Finkelhor D, Turner H, Ormrod R, Hamby S, Kracke K. Children's exposure to violence: A comprehensive national survey. Washington, DC: U.S. Office of Juvenile Justice and Delinquency Prevention. Bulletin OJJDP; 2009. Disponible en https:// www.ncjrs.gov/pdffiles1/ojjdp/224477.pdf

17. Secretaría General de Instituciones Penitenciarias. Ministerio del Interior. Mortalidad en Instituciones Penitenciarias 2014. [Internet]. 2015. Disponible en http://www.institucionpenitenciaria.es/ web/export/sites/default/datos/descargables/saludpublica/Mortalidad_en_IIPP_2014.pdf

18. Widom CS, DuMont K, Czaja SJ. A prospective investigation of major depressive disorder and comorbidity in abused and neglected children grown up. Arch Gen Psychiatry. 2007;64:49-56.

19. Widom CS. Childhood victimization: early adversity and subsequent psychopathology. En: Dohrenwend BP, editor. Adversity, stress and psychopathology. New York: Oxford University Press; 1998. p. 81-95.

20. Dube SR, Miller JW, Brown DW, Giles WH, Felitti VJ, Dong M, et al. Adverse childhood experiences and the association with ever using alcohol and initiating alcohol use during adolescence. J Adolesc Health. 2006;38:444.e1-10.

21. Kendler KS, Bulik CM, Silberg J, Hettema JM, Myers J, Prescott CA. Childhood sexual abuse and adult psychiatric and substance use disorders in women: an epidemiological and cotwin control analysis. Arch Gen Psychiatry. 2000;57:953-9.

22. Schilling C, Weidner K, Schellong J, Joraschky P, Pöhlmann, K. Patterns of childhood abuse and neglect as predictors of treatment outcome in inpatient psychotherapy: a typological approach. Psychopathology. 2014;48:91-100.

23. De Bellis MD, Zisk A. The biological effects of childhood trauma. Child Adolesc Psychiatric Clin N Am. 2014;23:185-222.

24. Shalev I, Moffitt TE, Sugden K, Williams B, Houts RM, Danese A, et al. Exposure to violence during childhood is associated with telomere erosion from 5 to 10 years of age: a longitudinal study. Mol Psychiatry. 2013;18:576-81. 
25. Altamirano Agudo Z. El bienestar psicológico en prisión: antecedentes y consecuencias. [Tesis doctoral]. Universidad Autónoma de Madrid; 2013. Dsiponible en: http://dialnet.unirioja.es/servlet/ tesis? codigo $=39129$

26. Bénèzech $M$, Rager $P$. Suicide et tentative de suicide en milieu carcéral: considérations générales. Psychologie Medicale. 1987;19:613-5.

27. Abram KM, Teplin LA, Charles DR, Longworth SL, McClelland GM, Dulcan MK. Posttraumatic stress disorder and trauma in youth in juvenile detention. Arch Gen Psychiatry. 2004;61: 403-10.

28. Komarovskaya I. Trauma, PTSD, and the cycle of violence among incarcerated men and women. [Unpublished Doctoral Dissertation]. University of Virginia. Lynchburg, Virginia; 2009.

29. Carr CP, Martins CM, Stingel AM, Lemgruber VB, Juruena MF. The role of early life stress in adult psychiatric disorders: a systematic review according to childhood trauma subtypes. J Nerv Ment Dis. 2013;201:1007-20.

30. Kingdon DG, Ashcroft K, Bhandari B, Gleeson S, Warikoo N, Symons M, et al. Schizophrenia and borderline personality disorder: similarities and differences in the experience of auditory hallucinations, paranoia, and childhood trauma. J Nerv Ment Dis. 2010;198:399-403.

31. Zanarini MC, Ruser TF, Frankenburg FR, Hennen J, Gunderson JG. Risk factors associated with the dissociative experiences of borderline patients. J Nerv Ment Dis. 2000;188:26-30.

32. Brown J, Cohen P, Johnson JG, Smailes EM. Childhood abuse and neglect: specificity of effects on adolescent and young adult depression and suicidality. J Am Acad Child Adolesc Psychiatry. 1999;38:1490-6.

33. Sarchiapone M, Jaussent I, Roy A, Carli V, Guillaume S, Jollant F, et al. Childhood trauma as a correlative factor of suicidal behavior - via aggression traits. Similar results in an Italian and in a French sample. Eur Psychiatry. 2009;24:57-62.

34. Dube SR, Anda RF, Felitti VJ, Chapman DP, Williamson DF, Giles WH. Childhood abuse, household dysfunction, and the risk of attempted suicide throughout the life span. JAMA. 2001;286:3089-96.

35. Carli V, Mandelli L, Poštuvan V, Roy A, Bevilacqua L, Cesaro C, et al. Self-harm in prisoners. CNS Spectr. 2011;16:75-81.

36. Jenkins R, Bhugra D, Meltzer H, Singleton N, Bebbington P, Brugha T, et al. Psychiatric and social aspects of suicidal behaviour in prisons. Psychol Med. 2005;35:257-69.
37. Secretaría General de Instituciones Penitenciarias. Ministerio del Interior. Prevención de suicidios [Internet]. Madrid. [actualizado 5 Jul 2017; citado 17 Sep 2017]. Disponible en: http://www.institucionpenitenciaria.es/web/portal/Reeducacion/ ProgramasEspecificos/prevencionSuicidios.html

38. Dutton DG, Hart SD. Evidence for long-term, specific effects of childhood abuse and neglect on criminal behavior in men. Int J Offender Ther Comp Criminol. 1992;36:129-73.

39. Driessen M, Schroeder T, Widmann B, Von Schönfeld CE, Schneider F. Childhood trauma, psychiatric disorders, and criminal behavior in prisoners in Germany: a comparative study in incarcerated women and men. J Clin Psychiatry. 2006;67:1486-92.

40. Mandellia L, Carlib V, Roy A, Serrettia A, Sarchiapone $\mathrm{M}$. The influence of childhood trauma on the onset and repetition of suicidal behavior: An investigation in a high risk sample of male prisoners. J Psychiatr Res. 2011;45:742-7.

41. Gorodetsky E, Carli V, Sarchiapone M, Roy A, Goldman D, Enoch M. Predictors for selfdirected aggression in Italian prisoners include externalizing behaviors, childhood trauma and the serotonin transporter gene polymorphism 5-HTTLPR. Genes Brain Behav. 2016;15:46573.

42. Swogger MT, Sungeun Y, Cashman-Brown S, Conner, KR. Childhood physical abuse, aggression, and suicide attempts among criminal offenders. Psychiatry Res. 2010;185:363-7.

43. Saavedra J, López M. Riesgo de suicidio de hombres internos con condena en centros penitenciarios. Rev Psiquiatr Salud Ment. 2015;8:197-252.

44. Sánchez FC, Fearn N, Vaughn MG. Risk Factors Associated With Near-Lethal Suicide Attempts During Incarceration Among Men in the Spanish Prison System. Int J Offender Ther Comp Criminol. 2018;62:1452-73.

45. Verona E, Hicks BM, Patrick CJ. Psychopathy and suicidality in female offenders: mediating influences of personality and abuse. J Consult Clin Psychol. 2005;73:1065-73.

46. Clements-Nolle K, Wolden M, Bargmann-Losche J. Childhood trauma and risk for past and future suicide attempts among women in prison. Women's Health Issues. 2009;19:185-92.

47. Ardino V. Post-traumatic stress in antisocial youth: A multifaceted reality. En: Ardino V, editor. Post-traumatic syndromes in children and adolescents. Chichester, UK: Wiley/Blackwell Publishers; 2011. p. 211-29. 
48. Foy D, Furrow J, McManus S. Exposure to violence, post-traumatic symptomatology, and criminal behaviors. En: Ardino V, editor. Posttraumatic syndromes in children and adolescents. Chichester, UK: Wiley/Blackwell Publishers; 2011. p. 199-210.

49. Weeks R, Widom CS. Self-reports of early childhood victimization among incarcerated adult male felons. J Interpers Violence. 1989;13:34661.

50. Kerig PK, Ward RM, Vanderzee KL, ArnzenMoeddel M. Posttraumatic stress as a mediator of the relationship between trauma and mental health problems among juvenile delinquents. J Youth Adolesc. 2009;38:1214-25.

51. Charles DR, Abram KM, McClelland GM, Teplin LA. Suicidal ideation and behavior among women in jail. J Contemp Crim Justice. 2003;19:65-81.
52. Browne A, Miller B, Maguin E. Prevalence and severity of lifetime physical and sexual victimization among incarcerated women. Int J Law Psychiatry. 1999;22:301-22.

53. Jordan BK, Schlenger WE, Fairbank JA, Cadell JM. Prevalence of psychiatric disorders among incarcerated women. II. Convicted felons entering prison. Arch Gen Psychiatry. 1996;53:513-9.

54. De Ravello L, Abeita J, Brown P. Breaking the cycle/mending the hoop: adverse childhood experiences among incarcerated American Indian/ Alaska Native women in New Mexico. Health Care Women Int. 2008;29:300-15.

55. Secretaría General de Instituciones Penitenciarias. Ministerio del Interior. Informe General 2016. [Internet]. Disponible en http://www.institucionpenitenciaria.es/web/export/sites/default/ datos/descargables/publicaciones/Informe_General_2016_acc.pdf 